\title{
Detection of Left Ventricular Regional Function in Asymptomatic Children with beta-Thalassemia Major by Longitudinal Strain and Strain Rate Imaging
}

\author{
Beta Talasemi Majör Tanılı Asemptomatik Çocuklarda Sol \\ Ventrikül Bölgesel Fonksiyonlarının Longitidunal Strain ve \\ Strain Rate Görüntüleme ile Değerlendirilmesi
}

\author{
Ali Bay¹, Osman Başpınar², Göksel Leblebisatan³, Ali Seçkin Yalçın' ${ }^{1}$, Ahmet İrdem² \\ ${ }^{1}$ Gaziantep University Medical Faculty, Department of Pediatric Hematology, Gaziantep, Turkey \\ ${ }^{2}$ Gaziantep University Medical Faculty, Department of Pediatric Cardiology, Gaziantep, Turkey \\ ${ }^{3}$ Gaziantep Children's Hospital, Department of Pediatric Hematology, Gaziantep, Turkey
}

\begin{abstract}
:
Objective: Cardiac failure due to iron overload remains the most common cause of death in patients with betathalassemia major. This study aimed to evaluate myocardial function in children with beta-thalassemia major using standard echocardiography technique and strain rate imaging.

Materials and Methods: Conventional echocardiographic analysis, tissue velocity imaging, and strain/strain rate imaging of the left ventricle were evaluated in 48 children with beta-thalassemia major (19 girls, 29 boys; 8.39 \pm 4.05 years) and 22 healthy children ( 11 girls, 11 boys; $8 \pm 3.72$ years).

Results: Conventional echocardiographic examinations revealed that beta-thalassemia patients had larger left ventricular endsystolic diameter, end-diastolic and end-systolic volume, left ventricular mass index, and mitral early/late diastolic flow velocity ratio $(\mathrm{p}<0.05)$. Strain and strain rate imaging study of the basal lateral wall of the left ventricle was higher in patients than in controls, at $\mathrm{p}=0.035$ and $\mathrm{p}=0.008$, respectively.

Conclusion: We found that superior systolic strain and strain rate imaging of the left ventricle indicated the presence of regional systolic function in the left ventricular wall. We suggest that left ventricle volume and mass index parameters might be more sensitive than the other conventional and strain/strain rate imaging parameters during childhood. However, the adulthood strain and strain rate imaging values may be lower than controls, exceeding the critical level of iron overload.
\end{abstract}

Key Words: Childhood, Regional left ventricular cardiac function, Strain, Strain rate imaging, Thalassemia

Özet:

Amaç: Beta talasemi majörlü hastalarda demir yüklenmesine bağlı kalp yetmezliği en sık ölüm nedenidir. Bu çalışmada beta talasemi majörlü çocuklarda standart ekokardiyografi ve strain rate görüntüleme ile myokardiyal fonksiyonun değerlendirilmesi amaçlanmıștır.

Address for Correspondence: Osman BAŞPINAR, MD,

Gaziantep University Medical Faculty, Department of Pediatric Cardiology, 27310 Gaziantep, Turkey

Phone: ++ 903423603928 E-mail: osmanbaspinar@hotmail.com

Received/Geliş tarihi : May 20, 2012

Accepted/Kabul tarihi : October 22, 2012 
Gereç ve Yöntemler: Çalışmamızda rutin ekokardiyografik değerlendirme ile beraber sol ventrikülün doku velosite

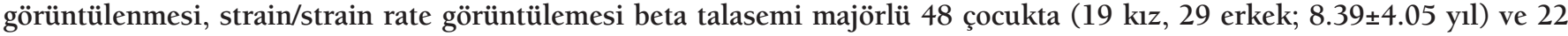
sağlıklı çocukta (11 kız, 11 erkek; $8 \pm 3.72$ yıl) ölçülmüştür.

Bulgular: Rutin ekokardiyografik değerlendirmede beta talasemi majörlü hastalarda daha geniş sol ventrikül sistol sonu çap, diyastol ve sistol sonu hacmi olduğu, kitlesinin artmış olduğu ve mitral kapak erken/geç diyastolik akım oranının artmış olduğu görüldü $(\mathrm{p}<0.05)$. Sol ventrikül bazal lateral duvarı strain ve strain rate görüntülemesi değerleri hasta grubunda kontrole göre anlamlı yüksek değerdeydi (sırası ile $\mathrm{p}=0.035$ ve $\mathrm{p}=0.008$ ).

Sonuç: Sol ventrikül superior strain ve strain rate görüntülemesinde sol ventrikül duvarının bölgesel sistolik fonksiyonunu koruduğunu bulduk. Çocukluk çağında sol ventrikül hacim ve kitle indeksi göstergelerinin diğer geleneksel ve strain/strain rate görüntüleme göstergelerine göre daha duyarlı olabileceğini düşünmekteyiz. Bununla beraber, erişkin döneminde demir yüklenmesinin kritik seviyeyi aşması ile strain ve strain rate görüntüleme değerleri kontrol olgularınınkinden daha düşük bulunabilir.

Anahtar Sözcükler: Çocukluk çağı, Bölgesel sol ventriküler kardiyak fonksiyonlar, Strain, Strain hız görüntüleme, Talasemi

\section{Introduction}

Cardiac failure due to iron overload remains the most common cause of death in patients with beta-thalassemia major, accounting for up to $71 \%$ of all deaths from this disease [1,2]. Cardiac complications are related to left ventricle dysfunction leading to gradual cardiac failure and cardiogenic death. Standard echocardiographic measurements may remain normal until late stages during this disease process.

A number of cardiological parameters of left ventricular (LV) function have therefore been assessed to determine their efficacy in identifying early myocardial iron overload in order to prevent heart failure and avert its poor prognosis through increased chelation therapy. The stored iron in the heart is heterogeneous. Regional myocardial asynchrony characterizes diastolic abnormalities even in the absence of changes in systolic functions reported in thalassemia patients and, thus, LV diastolic function may be more sensitive as an early marker of myocardial iron overload. A number of techniques used in clinical practice have been utilized to assess diastolic function in thalassemia major $[3,4,5]$.

Strain rate imaging (SRI) is a new noninvasive echocardiographic method for the analysis of local myocardial stress. SRI is potentially superior to tissue Doppler imaging (TDI) in regional myocardial function assessment $[6,7,8]$. This study aimed to evaluate myocardial function in children with beta-thalassemia major by using the standard echocardiography technique TDI and SRI and to compare them with healthy controls.

\section{Material and Method}

\section{Patient Population}

Two distinct groups were studied. The patient group comprised 48 beta-thalassemia major patients (19 girls, 29 boys; median 8 , mean $8.39 \pm 4.05$ years). Thalassemia major patients were selected from cases in follow-up in the
Gaziantep University Pediatric Hematology Department and Gaziantep Children's Hospital. The diagnosis of thalassemia was based on hemogram, blood smear, hemoglobin electrophoresis, and clinical evaluation. All patients were under chelation therapy with an oral iron chelator (deferasirox, $30 \mathrm{mg} / \mathrm{kg} / \mathrm{d}$ ) or a parenteral iron chelator (deferoxamine, $40 \mathrm{mg} / \mathrm{kg} 5$ days a week). Serum ferritin levels were noted as $\mathrm{ng} / \mathrm{mL}$. Inclusion criteria were diagnosis of beta-thalassemia major, normal renal function, normal left ventricular functions, normal estimated pulmonary pressures by echocardiographic Doppler evaluation, and absence of congenital or acquired structural heart or lung diseases. All thalassemia patients had asymptomatic heart failure and were in New York Heart Association functional class I. They had been receiving blood transfusions since the age of 6 months to 2 years. Twenty-three (47.9\%) of the patients had been splenectomized. Severity of iron overload was defined by serum ferritin level. Twenty-two healthy children (11 girls, 11 boys; $8 \pm 3.72$ years) without history of cardiac disease were included in the study as a control group. All children were in normal sinus rhythm and had normal resting 12-lead electrocardiographs. All studies were performed in accordance with the rules of the local ethics committee. Informed consent was obtained from all participants prior to the study.

\section{Echocardiography}

Conventional echocardiography (Vivid 3, GE Vingmed Ultrasound, Horten, Norway) and strain and strain rate imaging were performed by the same experienced pediatric cardiologist. Echocardiographic images were obtained in the parasternal long-axis and short-axis, and apical 2-chamber and 4-chamber views were obtained with standard transducer positions. Conventional echocardiographic measurements were done according to the American Society of Echocardiography guidelines [9]. Left ventricle mass was 
calculated using the Devereux formula [10]. Left ventricle mass index was calculated by dividing the left ventricle mass by body surface area. All examinations were videotaped and contemporary electrocardiography traces were recorded. From the parasternal long-axis view of the LV end-diastolic and end-systolic diameters, interventricular septal and posterior wall thicknesses were expressed in millimeters. We measured LV end-systolic and end-diastolic (EDV) volumes from the apical 4-chamber view. Left ventricle fractional shortening (FS) and ejection fraction (EF) were measured using the Teichholz formula. LV filling was evaluated by pulse wave Doppler from the apical 4-chamber view with the sample volume position at the tips of the mitral valve, and velocities in early (E) and late (A) diastole were recorded, in addition to the calculation of the E/A ratio. Furthermore, myocardial velocities of the left ventricle were evaluated by tissue velocity imaging (TVI), strain (S), and SRI.

Digital data of color TDI were transferred for offline analysis with EchoPAC-PC software (GE Vingmed Ultrasound). Scanning was performed longitudinally from the apex to acquire apical 2-chamber and 4-chamber views with a 3-MHz transducer and a frame rate of $100 \pm$ 20 frames/s, depending on the heart rate, to minimize the noise level. Myocardial velocities were measured for the local motion of a tissue by TVI and S, and the local rates of deformations were measured by SRI. Longitudinal strain and strain rate in the basal septal, basal lateral, mid-septal, and mid-lateral wall were estimated by measuring the spatial velocity gradient over a computational area of $3 \mathrm{~mm} \times 5$ $\mathrm{mm}$. Tissue velocity, strain, and strain rate were obtained at each site from 3 consecutive $b$ eats and average values were calculated. End-diastole was defined as the R peak in echocardiography, and end-systole was defined as the end of the $\mathrm{T}$ wave in echocardiography. Peak positive systolic values were calculated from the extracted curve. From the 4-chamber view, the TVI sample volume was located sequentially at septal and lateral sites of the valvular ring. Mean values of early diastolic, late diastolic, and systolic myocardial velocities were calculated as $\mathrm{cm} / \mathrm{s}$.

\section{Statistical Analysis}

Statistical analysis was performed using SPSS 11.0 (SPSS Inc., Chicago, IL, USA). All data were expressed as mean \pm standard derivation. Comparison of measurements between 2 groups was analyzed with the unpaired Student t-test. Correlation coefficients between various measurements were determined by the linear regression analysis. A p value of less than 0.05 was considered significantly different.

\section{Results}

The demographic characteristics of the patients with beta-thalassemia major and the control group are presented in Table 1. The 2 groups were similar regarding age and body surface area. Conventional echocardiographic examinations revealed that beta-thalassemia patients had larger LV endsystolic diameter $(\mathrm{cm})$, end-diastolic and end-systolic volume $(\mathrm{mL}), \mathrm{LV}$ mass index $\left(\mathrm{g} / \mathrm{m}^{2}\right)$, and mitral early/late diastolic flow velocity ratio. Mitral early-to-late diastolic flow velocity ratio as determined by conventional echocardiography was significantly higher in thalassemia major patients compared to the control group (Table 2).

In the TVI technique, left ventricle lateral late diastolic myocardial velocity was lower in beta-thalassemia patients compared to the control group, and the lateral early-tolate diastolic myocardial velocity ratio was higher in betathalassemia patients compared to the control group (Table 3 ). Strain and SRI study included the following measurements: basal lateral and septal segments and mid-lateral and septal segments of the LV walls. The basal lateral walls' S and SRI measurements were higher in patients compared to controls: $\mathrm{p}=0.035$ and $\mathrm{p}=0.008$, respectively (Tables 4 and 5 ).

Pearson's correlation coefficient showed significant correlations between the serum ferritin levels and the following echocardiographic variables: LV end-diastolic volumes $(\mathrm{r}=0.288, \mathrm{p}=0.049), \mathrm{LV}$ end-systolic volumes $(\mathrm{r}=0.354, \mathrm{p}=0.015), \mathrm{EDV}(\mathrm{r}=0.288, \mathrm{p}=0.049), \mathrm{EF}(\mathrm{r}=-0.380$, $\mathrm{p}=0.008)$, FS $(\mathrm{r}=-0.378, \mathrm{p}=0.009), \mathrm{E}(\mathrm{r}=-0.302, \mathrm{p}=0.044)$, septal early TVI $(\mathrm{r}=-0.329, \mathrm{p}=0.026)$, and lateral systolic TVI $(\mathrm{r}=-0.330, \mathrm{p}=0.025)$.

Table 1. Demographic and hematologic characteristics of the patient and control groups.

\begin{tabular}{|l|l|l|l|}
\hline Sex & Patient group $(\mathbf{n = 4 8 )}$ & Control group $(\mathbf{n = 2 2})$ & p \\
\hline Age (years) & 19 girls, 29 boys & 11 girls, 11 boys & \\
\hline Height $(\mathrm{cm})$ & $8.4 \pm 4.5(2-16)$ & $8.0 \pm 3.7(2-14)$ & 0.702 \\
\hline Weight $(\mathrm{kg})$ & $119.77 \pm 19.67(85-156)$ & $126.59 \pm 23.03(88-175)$ & 0.242 \\
\hline Body surface area $\left(\mathrm{m}^{2}\right)$ & $23.28 \pm 8.69(10-42)$ & $30.09 \pm 14.54(12-66)$ & 0.052 \\
\hline Mean serum ferritin $(\mu \mathrm{g} / \mathrm{L})$ & $0.87 \pm 0.23(0.54-1.34)$ & $1.01 \pm 0.32(0.53-1.64)$ & 0.092 \\
\hline Splenectomy $(\%)$ & $2543.75 \pm 1790.65(454-7669)$ & - & \\
\hline
\end{tabular}


Table 2. Conventional and basic systolic and diastolic echocardiographic parameters of the patient and control groups.

\begin{tabular}{|c|c|c|c|}
\hline & Patients $(n=48)$ & Controls $(n=22)$ & p \\
\hline Left atrial diameter $(\mathrm{cm})$ & $2.44 \pm 0.47$ & $2.41 \pm 0.44$ & 0.824 \\
\hline Aortic diameter $(\mathrm{cm})$ & $2.13 \pm 0.35$ & $2.18 \pm 0.42$ & 0.635 \\
\hline Left atrial/aortic diameter ratio & $1.16 \pm 0.19$ & $1.12 \pm 0.16$ & 0.412 \\
\hline Left ventricular end-diastolic diameter (cm) & $3.89 \pm 0.67$ & $3.59 \pm 0.51$ & 0.052 \\
\hline Left ventricular end-systolic diameter (cm) & $2.46 \pm 0.54$ & $2.10 \pm 0.45$ & $0.006^{*}$ \\
\hline Diastolic interventricular septal thickness (cm) & $0.74 \pm 0.15$ & $0.75 \pm 0.11$ & 0.767 \\
\hline Systolic interventricular septal thickness (cm) & $1.01 \pm 0.18$ & $1.06 \pm 0.19$ & 0.317 \\
\hline Diastolic posterior wall thickness (cm) & $0.64 \pm 0.14$ & $0.63 \pm 0.15$ & 0.818 \\
\hline Systolic posterior wall thickness (cm) & $0.95 \pm 0.15$ & $0.90 \pm 0.12$ & 0.123 \\
\hline Left ventricular end-diastolic volume (mL) & $68.78 \pm 27.45$ & $55.90 \pm 19.20$ & $0.030^{*}$ \\
\hline Left ventricular end-systolic volume (mL) & $23.97 \pm 14.50$ & $16.66 \pm 6.90$ & $0.006^{*}$ \\
\hline Left ventricular stroke volume (mL) & $46.25 \pm 17.81$ & $39.33 \pm 13.03$ & 0.078 \\
\hline Left ventricular ejection fraction (\%) & $67.85 \pm 7.54$ & $70.66 \pm 4.53$ & 0.062 \\
\hline Left ventricular fractional shortening (\%) & $37.61 \pm 5.74$ & $39.38 \pm 3.66$ & 0.133 \\
\hline Left ventricular mass (g) & $80.92 \pm 39.49$ & $67.48 \pm 33.67$ & 0.159 \\
\hline Left ventricular mass index $\left(\mathrm{g} / \mathrm{m}^{2}\right)$ & $86.14 \pm 25.47$ & $64.28 \pm 17.50$ & $0.000^{*}$ \\
\hline Mitral early diastolic flow velocity (m/s) & $1.00 \pm 0.20$ & $1.00 \pm 0.12$ & 0.990 \\
\hline Mitral late diastolic flow velocity (m/s) & $0.51 \pm 0.13$ & $0.56 \pm 0.10$ & 0.082 \\
\hline Mitral early/late diastolic flow velocity ratio & $2.09 \pm 0.51$ & $1.78 \pm 0.21$ & $0.001^{*}$ \\
\hline
\end{tabular}

Data expressed as means \pm standard deviations, * statistically significant.

\section{Discussion}

The most common cause of morbidity and mortality in thalassemia major patients is cardiomyopathy due to iron overload. Heart disease is mainly expressed by a particular cardiomyopathy that progressively leads to heart failure and death $[1,2,11]$. Iron toxicity has been attributed to the production of free oxygen radicals, as a result of the Fenton and Haber-Weiss reactions, which take place in the presence of free iron, the most toxic form of iron.

Since cardiac function remains normal until late stages in the spectrum of iron cardiomyopathy, other tools are necessary to anticipate and prevent iron cardiomyopathy. Cardiac magnetic resonance imaging, tissue Doppler echocardiography, radionuclide angiography, and stress echocardiography are useful imaging studies for the detection of early cardiac dysfunction. Recently, tissue Doppler echocardiography and radionuclide angiography (with exercise or low-dose dobutamine stimulation) have been shown to detect regional wall motion abnormality, even in early-stage thalassemic patients [11]. This finding may also reflect patchy, nonhomogeneous deposition of iron in cardiac muscle.
Fitchett et al. demonstrated the deposition of iron within the myocytes rather than the interstitium, and this cardiac iron deposition was patchy [12]. Lattanzi et al. and Vogel et al. showed that regional wall motion abnormalities and regional iron overload were seen in patients with betathalassemia major $[13,14]$. These regional changes can be easily detected with an echocardiographic assessment including TVI and S/SRI analysis.

The novel contribution of ourstudy is the demonstration of the superiority of SI over the conventional echocardiographic parameters, LVEF and LVFS, in the detection of regional myocardial function. Our patients had superior systolic $S$ and SRI of the LV lateral wall, indicating the presence of regional systolic function in the left ventricular wall. We suggest that LV volume and mass index parameters might be more sensitive than the other conventional and S/SRI echocardiographic parameters. However, adulthood S/SRI sensitivity may be lower than in the controls.

Regular clinical follow-up is strongly recommended for precocious detection of symptoms and signs of myocardial dysfunction [15]. On the hypothesis that longitudinal ventricular function may give early information about 
Table 3. Left ventricular tissue velocity imaging $(\mathrm{cm} / \mathrm{s})$ parameters of the patient and control groups.

\begin{tabular}{|l|l|l|l|} 
& Patients (n=48) & Controls (n=22) & P \\
\hline Septal systolic myocardial velocity & $0.8 \pm 0.2$ & $0.8 \pm 0.1$ & 0.264 \\
\hline Septal early diastolic myocardial velocity & $1.5 \pm .0 .3$ & $1.6 \pm 0.2$ & 0.104 \\
\hline Septal late diastolic myocardial velocity & $0.7 \pm 0.6$ & $0.7 \pm 0.2$ & 0.989 \\
\hline Septal early/late diastolic myocardial velocity ratio & $2.34 \pm 0.76$ & $2.17 \pm 0.57$ & 0.328 \\
\hline Lateral systolic myocardial velocity & $0.7 \pm 0.2$ & $0.8 \pm .0 .1$ & 0.091 \\
\hline Lateral early diastolic myocardial velocity & $1.9 \pm 0.5$ & $1.9 \pm 0.3$ & 0.923 \\
\hline Lateral late diastolic myocardial velocity & $0.6 \pm 0.2$ & $0.8 \pm 0.1$ & $0.001^{*}$ \\
\hline Lateral early/late diastolic myocardial velocity ratio & $3.10 \pm 0.84$ & $2.42 \pm 0.55$ & $0.001^{*}$
\end{tabular}

Data expressed as means \pm standard deviations, * statistically significant.

Table 4. Left ventricular strain (\%) parameters of the patient and control groups.

\begin{tabular}{|l|l|l|l|}
\hline & $\begin{array}{l}\text { Patients } \\
(\mathbf{n}=48)\end{array}$ & $\begin{array}{l}\text { Controls } \\
(\mathbf{n}=22)\end{array}$ & P \\
\hline Basal lateral wall & $13.99 \pm 11.08$ & $9.13 \pm 7.36$ & $0.035^{*}$ \\
\hline Mid-lateral wall & $9.00 \pm 6.97$ & $11.22 \pm 7.27$ & 0.238 \\
\hline Basal septal wall & $11.09 \pm 8.58$ & $11.28 \pm 9.30$ & 0.936 \\
\hline Mid-septal wall & $13.84 \pm 10.22$ & $16.11 \pm 7.65$ & 0.310 \\
\hline
\end{tabular}

Data expressed as means \pm standard deviations.

Table 5. Left ventricular strain rate imaging ( $1 / \mathrm{s})$ parameters of the patient and control groups.

\begin{tabular}{|l|l|l|l|}
\hline & $\begin{array}{l}\text { Patients } \\
(\mathbf{n = 4 8})\end{array}$ & $\begin{array}{l}\text { Controls } \\
(\mathbf{n = 2 2})\end{array}$ & P \\
\hline Basal lateral wall & $1.27 \pm 0.9$ & $0.82 \pm 0.46$ & $0.008^{*}$ \\
\hline Mid-lateral wall & $0.97 \pm 0.66$ & $0.70 \pm 0.49$ & 0.064 \\
\hline Basal septal wall & $1.16 \pm 0.88$ & $1.17 \pm 0.58$ & 0.981 \\
\hline Mid-septal wall & $1.34 \pm 0.88$ & $1.07 \pm 0.40$ & 0.083 \\
\hline
\end{tabular}

Data expressed as means \pm standard deviations.

impending ventricular function, we used TVI and S/ SRI measurements [6,7]. Regional findings suggest the presence of differences in myocardial function between the asymptomatic patients with beta-thalassemia major in the early stage of disease and the healthy controls. These regional changes can be easily detected with an echocardiographic assessment including TVI and S/SRI analysis.

Previous studies have shown that beta-thalassemia major is frequently associated with progressive LV dysfunction, leading to congestive heart failure. LV diastolic function, measured by traditional measurements such as transmitral flow recordings, is preserved until the final stages of diseases $[16,17,18]$. Conventional Doppler indices frequently lead to incorrect diagnosis.
In our patients, chronic iron overload resulted in significant increase in serum ferritin and significantly increased LVMI. However, EF and FS were not altered significantly in patients compared with controls, suggesting preserved systolic functioning until late stages of the disease. This finding is consistent with those of Parale et al. and Seliem et al. [18,19].

Magri et al. suggested TDI and strain imaging as a potential method for detecting early stages of abnormal iron deposition [20]. Olivieri et al. and Bosi et al. demonstrated that serum levels of ferritin below $2500 \mathrm{ng} / \mathrm{mL}$ were considered as the safe level $[1,21]$. Our mean value of serum ferritin was at this level. Fitchett et al. demonstrated iron deposition within the myocytes rather than the interstitium and this cardiac iron deposition was patchy [12]. Lattanzi et al. and Vogel et al. showed that regional wall motion abnormalities and regional iron overload were seen in patients with beta-thalassemia major $[13,14]$. We found wall motion abnormality located in the basal lateral segment of the LV wall. There is no clear explanation for this observation.

S/SRI offers a new way of measuring regional tissue deformation noninvasively with both good spatial and temporal resolution. Authors have demonstrated it to be a tool that would appear to offer reproducible and reliable data [8]. Our findings suggest that S/SRI parameters have the potential to detect early myocardial changes that precede abnormal LV filling.

This study demonstrates the ability of S/SRI to accurately depict regional myocardial function in asymptomatic betathalassemia patients with normal systolic and diastolic function. LV dilatation or increased LVMI was balanced with increased basal segment S/SRI measurements. During this period, increased LV dilatation may progress to lower S/SRI values and to LV diastolic and systolic function disorders. Until the critical level of iron overload, peak systolic strain and SRI may accurately reflect local systolic function, and we may say that iron overload is not related to a specific area of LV myocardium and that cardiac changes are possibly related to a threshold level of iron overload. 
While serum ferritin levels remain above $2500 \mu \mathrm{g} / \mathrm{L}$, echocardiographic measurements such as basal TVI, S, and SRI parameters might show compensatory increase although LV dilatation starts with normal systolic function. This compensation would probably be inadequate at greater ferritin levels and systolic and diastolic functions would globally decrease eventually. Therefore, clinical manifestations usually occur in adulthood rather than childhood. According to the Frank-Starling law, if heart volume increases, this compensation might be inadequate, and these parameters worsen through adulthood.

Accurate assessments of cardiac dysfunction and cardiac iron status are currently based on imaging techniques. The T2-star magnetic resonance is currently the best noninvasive modality to estimate iron in the heart and other organs [22]. In addition, it can be used for monitoring myocardial iron levels during iron chelation therapy. Unfortunately this examination cannot be performed in our hospital; we could not correlate this technique with the results.

One of the limitations of our study is that we could not compare the patients within every ferritin level. In asymptomatic patients, normal systolic and diastolic functions might be related to good LV compensation. Strengthening the chelation treatment in this period may normalize these measurements. Even when LVEF and LVFS are normal, increased LV mass and volume may be seen. In this study we found compensatory increase in $S$ and SRI measurements, and these parameters would probably worsen first to be followed by cardiac failure appearing due to decreased LVEF and LVFS.

\section{Conflict of Interest Statement}

The authors of this paper have no conflicts of interest, including specific financial interests, relationships, and/ or affiliations relevant to the subject matter or materials included.

\section{References}

1. Olivieri NF, Nathan DG, MacMillan JH, Wayne AS, Liu PP, McGee A, Martin M, Koren G, Cohen AR. Survival in medically treated patients with homozygous betathalassemia. N Eng J Med 1994;331:574-578.

2. Leonardi B, Margossian R, Colan SD, Powell AJ. Relationship of magnetic resonance imaging estimation of myocardial iron to left ventricular systolic and diastolic function in thalassemia. JACC Cardiovasc Imaging 2008;1:572-578.

3. Chrysohoou C, Greenberg M, Pitsavos C, Panagiotakos DB, Ladis V, Barbetseas J, Brili S, Singh S, Stefanadis C. Diastolic function in young patients with beta-thalassemia major: an echocardiographic study. Echocardiography 2006;23:38-44.

4. Aypar E, Alehan D, Hazirolan T, Gümrük F. The efficacy of tissue Doppler imaging in predicting myocardial iron load in patients with beta-thalassemia major: correlation with T2* cardiovascular magnetic resonance. Int J Cardivasc Imaging 2010;26:413-421.
5. Balci YI, Gurses D. Detection of early cardiac dysfunction in patients with $\beta$-thalassemia major and thalassemia trait by tissue doppler echocardiography. Pediatr Hematol Oncol 2011;28:486-496.

6. Nesbitt GC, Mankad S. Strain and strain rate imaging in cardiomyopathy. Echocardiography 2009;26:337-344.

7. Nesbitt GC, Mankad S, Oh JK. Strain imaging in echocardiography: methods and clinical applications. Int J Cardiovasc Imaging 2009;25:9-22.

8. Voigt JU, Lindenmeier G, Werner D, Flachskampf FA, Nixdorff U, Hatle L, Sutherland GR, Daniel WG. Strain rate imaging for the assessment of preload-dependent changes in regional left ventricular diastolic longitudinal function. J Am Soc Echocardiogr 2002;15:13-19.

9. Sahn DJ, DeMaria A, Kisslo J, Weyman A. Recommendations regarding quantitation in M-mode echocardiography: results of a survey of echocardiographic measurements. Circulation 1978;58:1072-1083.

10. Devereux RB. Detection of left ventricular hypertrophy by M-mode echocardiography. Anatomic validation, standardization, and comparison to other methods. Hypertension 1987;9:19-26.

11. Cohen AR, Galanello R, Pennell DJ, Cunningham MJ, Vichinsky E. Thalassemia. Hematology Am Soc Hematol Educ Program 2004:14-34.

12. Fitchett DH, Coltart DJ, Littler WA, Leyland MJ, Trueman T, Gozzard DI, Peters TJ. Cardiac involvement in secondary haemochromatosis: a catheter biopsy study and analysis of myocardium. Cardiovasc Res 1980;14:719-724.

13. Lattanzi F, Bellotti P, Picano E, Chiarella F, Mazzarisi A, Melevendi C, Forni G, Landini L, Distante A, Vecchio C. Quantitative ultrasonic analysis of myocardium in patients with thalassemia major and iron overload. Circulation 1993;87:748-754.

14. Vogel M, Anderson LJ, Holden S, Deanfield JE, Pennell DJ, Walker JM. Tissue Doppler echocardiography in patients with thalassaemia detects early myocardial dysfunction related to myocardial iron overload. Eur Heart J 2003;24:113-119.

15. Marcí M, Pitrolo L, Lo Pinto C, Sanfilippo N, Malizia R. Detection of early cardiac dysfunction in patients with Beta thalassemia by tissue Doppler echocardiography. Echocardiography 2011;28:175-180.

16. Koren A, Garty I, Antonelli D, Katzuni E. Right ventricular cardiac dysfunction in beta-thalassemia major. Am J Dis Child 1987;141:93-96.

17. Kremastinos DT, Tsiapras DP, Tsetsos GA, Rentoukas EI, Vretou HP, Toutouzas PK. Left ventricular diastolic Doppler characteristics in beta-thalassemia major. Circulation 1993;88:1127-1135. 
18. Parale GP, Pawar SS, Tapare VS. Assessment of LV diastolic function in patients with beta-thalassemia major with special reference to E/Eann ratio. J Pediatr Hematol Oncol 2009;31:69-73.

19. Seliem MA, Al-Saad HI, Bou-Holaigah IH, Khan MN, Palileo MR. Left ventricular diastolic dysfunction in congenital chronic anaemias during childhood as determined by comprehensive echocardiographic imaging including acoustic quantification. Eur J Echocardiogr 2002;3:103-110.

20. Magrì D, Sciomer S, Fedele F, Gualdi G, Casciani E, Pugliese P, Losardo A, Ferrazza G, Pasquazzi E, Schifano E, Mussino E, Quaglione R, Piccirillo G. Early impairment of myocardial function in young patients with beta-thalassemia major. Eur J Haematol 2008;80:515-522.
21. Bosi G, Crepaz R, Gamberini MR, Fortini M, Scarcia S, Bonsante E, Pitscheider W, Vaccari M. Left ventricular remodelling, and systolic and diastolic function in young adults with beta thalassaemia major: a Doppler echocardiographic assessment and correlation with haematological data. Heart 2003;89:762-766.

22. Anderson LJ. Assessment of iron overload with T2* magnetic resonance imaging. Prog Cardiovasc Dis 2011;54:287-294. 